Article

\title{
Quality Education as a Sustainable Development Goal in the Context of 2030 Agenda: Bibliometric Approach
}

\author{
Erika González García ${ }^{1}\left[\right.$ D , Ernesto Colomo Magaña ${ }^{2, * \mathbb{D}}$ and Andrea Cívico Ariza ${ }^{3}$ \\ 1 Department of Pedagogy, University of Granada, 18011 Granada, Spain; erikag@ugr.es \\ 2 Department of Theory and History of Education, University of Málaga, 29010 Málaga, Spain \\ 3 Education area, International University of Valencia, 46002 Valencia, Spain; andrea.civico@campusviu.es \\ * Correspondence: ecolomo@uma.es
}

Received: 23 June 2020; Accepted: 20 July 2020; Published: 22 July 2020

check for updates

\begin{abstract}
Quality education is understood as one of the most powerful and proven drivers for ensuring sustainable development, which can be applied in various educational contexts, formal and non-formal, and which can generate multiple benefits for the general public. Given its relevance, this article presents a bibliometric approach of the scientific production generated around Sustainable Development Goal (SPG) 4 that seeks to "Ensure inclusive and quality education for all and promote lifelong learning" as a priority objective of 2030 Agenda. To develop this research, a literature search was conducted in the Web of Science and Scopus databases. The final sample was 240 publications. The data were analyzed around ten variables: year of publication, type of document, area of indexation, periodical publications, most productive authors, institutions, countries, languages, most cited articles, and key words. The findings of this study indicate that quality education, within the Sustainable Development Goals, is gaining relevance, with 2019 being the year with the highest scientific production. This is a growing theme that is transmitted mainly through articles and papers in English, and there are no institutions, research groups or authors with a broad scientific background and production. The conclusion is that this bibliometric approach is important and necessary to know the reality of scientific production on this subject and to be able to make proposals and lines of research for its development.
\end{abstract}

Keywords: quality education; Sustainable Development Goals; 2030 Agenda; bibliometric study; scientific production

\section{Introduction}

The United Nations (UN) Sustainable Development Goals (SDGs) are not the first set of goals designed to help nations work together to create a cleaner planet and a more just global society. In 1987, the World Commission on Environment and Development produced a document for the United Nations called: "Our Common Future", also known as the Brundland Report, where the term Sustainable Development was popularized and was translated into Spanish as desarrollo sostenible (DS), sustainable development or durable development [1]. Sustainable development is, without doubt, a concept that has been written about, commented on, and researched extensively over time. Our work presents a bibliometric analysis of the scientific production generated around Sustainable Development Goal (SDG) 4 that seeks to "Ensure inclusive and quality education for all and promote lifelong learning" as a priority objective of 2030 Agenda. 


\subsection{Continuous Improvement of Education: Different Proposals and Initiatives at a Global Level}

Education for All (EFA) has been a worldwide movement coordinated by the United Nations Education, Scientific and Cultural Organisation (UNESCO) and whose main objective was to satisfy the basic needs of the population in terms of education and learning by the year 2015 [2]. This movement began in 1990 at the World Conference on Education for All: Meeting Basic Learning Needs, held in Jomtien, Thailand and convened by the World Bank, the United Nations Development Programme (UNDP), and the United Nations International Children's Fund (UNICEF). It brought together members from both countries and associations recognizing the need to provide a broad vision of education for present and future generations by proclaiming the World Declaration on Education for All. Later, in 2002, the international community met again at the World Education Forum in Dakar, where the six key Education for All (EFA) goals were set and identified, relating to (1) expanding early childhood education, especially for the most vulnerable children; (2) ensuring that by 2015 all children have access to and complete free and compulsory primary education of good quality and that no one drops out of school; (3) ensuring equitable access to and completion of education throughout life; (4) achieving universal primary education by 2015; (5) eliminating gender disparities in education by ensuring full and equal access to and achievement in basic education of good quality; and (6) improving all aspects of the quality of education and ensuring excellence of all so that recognized and measurable learning outcomes are achieved by all, especially in literacy, numeracy, and essential life skills. All these goals aim to make education universal from early childhood and throughout life, and to ensure that states make the necessary efforts to compensate for socio-cultural inequalities so that no child is excluded from a quality education system.

As noted above, Goal Six, "Quality of Education", will be our study topic [2]. These goals also contributed to the global pursuit of the eight Millennium Development Goals (MDGs) to be achieved by 2015 which included: (1) eradicating extreme poverty and hunger; (2) achieving universal primary education; (3) promoting gender equality and empowering women; (4) reducing child mortality; (5) improving maternal health; (6) combating Human Immunodeficiency Virus/Acquired Immune Deficiency Syndrome (HIV/AIDS), malaria, and other diseases; (7) ensuring environmental sustainability; and (8) developing a global partnership for development [3-7]. The Millennium Goals emphasize the need to link social and economic development with quality education. Health, quality of life, and equality are the pillars on which quality education should be developed. The problems are interrelated.

\subsection{Agenda and Quality Education}

In January 2016, a more ambitious strategy was proposed, and the number of objectives increased from eight to seventeen and 169 targets. This is an ambitious plan to achieve a sustainable future for all. All the goals are interlinked and incorporate the global challenges we face every day, such as poverty, inequality, climate, environmental degradation, prosperity, peace, justice and ensuring inclusive, equitable and quality education and promoting lifelong learning opportunities for all, which is at the heart of this work. In short, it is a matter of addressing issues of "economic growth, social development and environmental protection" because without them, it is impossible to address the issue of quality education for all [7].

Despite these efforts, policy strategies are often still "isolated" and address unique rather than common problems, and thus achievement of the SDGs is still far away [8]. To measure the scope and achievement of the SDGs, the UN introduced a series of indicators [9] that are broken down into different levels. These indicators guide countries with different statistics to define their inputs and contributions to the fulfillment of 2030 Agenda. So far, the achievement of these goals is at a low level [10]. In light of these facts, there is still a long way to go towards achieving the SDGs. Efforts must be combined in all areas and fields of social, economic, and political life, as well as in the areas of education and research [11]. Working from a sustainable development perspective and 
with an international perspective allows collective decisions to be made and changes to be projected, recognizing some global problems such as climate change, poverty or loss of biodiversity [12].

While the MDGs were primarily focused on developing countries, the Sustainable Development Goals cover all countries of the world, thus forming 2030 Agenda. It represents a major advance as a cosmopolitan proposal for a "global deal for development". It is an agenda of universal validity, not limited to the poorest countries, although it recognizes their specificity, and at the same time has the capacity to adapt to the diverse existing realities, at the regional, national, and local scales [13]. The aim is to create a sustainable path for economic growth, always based on respect for human rights, freedom, and the promotion of peace [14]. In this way, 2030 Agenda makes it possible to work, from a holistic and global perspective, on the social, economic, and environmental challenges facing our reality, in an attempt to achieve harmony and shared prosperity between humanity and the planet [15]. This is a commitment at all levels and scales, forming part of the political, social, environmental, and educational initiatives of countries, as well as the various institutions or companies that are part of the productive fabric and also play a key role [16]. The new document distinguishes between cognitive, socio-emotional, and behavioral learning objectives for all SDGs. It refers to the knowledge and skills needed to meet these objectives, the motivation and attitudes that can support them, and the actions needed to achieve them $[17,18]$. The objectives also seek to achieve equality among people, protect the planet, and ensure prosperity as part of a new Sustainable Development Agenda. They also serve to create a standard of benchmarking to measure progress towards the achievement of objectives and targets. The UN SDGs are concerned with having a global vision and being the roadmap to sustainability [19].

In the year 2015, the city of Incheon, South Korea celebrated and promulgated the Incheon Declaration and Framework for Action for the achievement of Sustainable Development Goal 4 "Ensure inclusive and equitable quality education and promote lifelong learning opportunities for all" [20], which proposes a new vision for education for the next 15 years. This objective is broken down into seven expected outcomes and three means; the targets are (4.1) quality of primary and secondary education; (4.2) quality of pre-primary education; (4.3) equal access to higher education; (4.4) employability skills; (4.5) gender disparity and vulnerable groups; (4.6) literacy and numeracy; (4.7) comprehensive education for sustainable development; (4.a) inclusive and safe educational facilities; (4.b) scholarships for higher education; and (4.c) teacher qualifications [21,22]. UNESCO itself, as part of the UN, works on the achievement of the Sustainable Development Goals through its Chairs [19], paying special attention to the achievement of Goal 4, coinciding with the focus of analysis in our work.

"Quality Education" is undoubtedly central to the achievement of 2030 Agenda, since it is an objective in itself and because education is not explicitly limited to Goal 4, but is linked to all the other objectives [23-25], such as Goal 3 on "Ensuring a healthy life and promoting the well-being of all people at all ages". Thus, good sex education can prevent early pregnancies and deaths of women and girls and prevent the spread of sexually transmitted diseases such as HIV [26]. However, it is surprising to note that in the health sector, particularly since the advent of science, technology, and innovation (STI), ways of producing new technologies for profit that are highly capital-intensive have been established in recent decades, which not only threaten the sustainability of health systems worldwide, but also do not respond to the health needs of the most disadvantaged populations [27].

The Incheon Declaration is a historic commitment by all of us to transform lives through a new vision of education, with bold and innovative measures. In this sense, education is a key area for the promotion and acquisition of competencies, knowledge, attitudes, social skills, healthy lifestyles, and participatory norms linked to sustainable development [28]. It is the perfect ground for current generations to internalize the importance of developing without compromising the possibility that future generations will be able to do so as well [29-31]. We must therefore generate spaces for debate and reflection where people can analyze, understand, internalize, and put into practice actions in favor of sustainable development, with the educational context being the ideal framework for working on 
2030 Agenda. This is a commitment that should be present in all stages of formal education, and also in the context of non-formal and informal education, since reflection and awareness of this area should be encouraged in all areas. Furthermore, "individuals as part of society should also be empowered to act in complex situations in a sustainable manner" [32]. Therefore, we must be able to offer models of responsibility and civic commitment to society and its progress, always safeguarding the environment. It is a shared responsibility of all citizens, educational institutions, and regulatory governments to achieve our ambitious goal by 2030 .

We still have a long way to go in the field of education, as can be seen in a new study on out-of-school children, which highlighted the minimal progress that has been made over a period of more than a decade. Last year, in 2019, 258 million children were left out of school. The report highlights the gap between poor and rich countries and the possibility of failing to achieve the Sustainable Development Goal dedicated to education [33]. Increased efforts are needed to make further progress and achieve the goals of universal education. However, the starting point is not zero and there are many lessons to be learned from the whole journey so far, both from EFA and from the other agencies that have worked more or less successfully to make education more equitable, inclusive, and of good quality for all people everywhere. All this should help us to work more effectively and more quickly in the coming years [34].

Education is the basis for improving our lives and for sustainable development. In addition to enriching people's quality of life, access to inclusive and equitable education can contribute by providing people with the tools to develop innovative solutions to the world's major problems.

Based on this reality, the research problem we face is limited to approaching the existing body of knowledge from science on the importance of quality education for sustainable development. For all these reasons, this study aims to perform a bibliometric approximation about scientific production with the greatest impact on educational quality in the context of SDGs and 2030 Agenda in the main international databases of a multidisciplinary nature: Web of Science (WoS) and Scopus. Under this premise, the following hypothesis is established: there is not yet a broad corpus of knowledge on the subject, nor authors or institutions specialized in it.

\section{Materials and Methods}

To achieve this purpose, a meta-analysis was carried out in which the publications were quantified and statistical methods were applied that have made it possible to know the reality and current state of this scientific subject, following the guidelines and criteria of bibliometric studies [35]. This is a technique that allows us to make a synthesis, of a scientific nature, on a subject, to know the findings that have been achieved, and to raise possible future research from a more objective approach [36-38]. Bibliometric approaches, in which different variables linked to scientific production on a subject are analyzed, allow us to know the reality of this area of knowledge. It is a very useful research method for approaching and examining a subject, allowing us to know what are the main publications, authors, and institutions of reference, as well as the main trends with respect to subjects and the links that underlie and are generated between the fields of knowledge [38,39]. Using this method, several research projects have addressed the issue of sustainable development [11,28,40-43]. Thus, we find works that have analyzed variables such as the country of origin of the publications, the key words proposed or the themes analyzed linked to sustainable development (water, environment, sustainable urban development or human ecology).

In addition to the bibliometric approach, techniques have also been used to analyze the relationships generated (relational nodes) between the descriptors of the different publications, using the VOSviewer software version 1.6.15 (Centre for Science and Technology, Leiden University, Leiden, The Netherlands) to visually represent these links.

The bibliometric approach was carried out following the tasks of scanning and curating the sample. 


\subsection{Scanning Phase}

To address the above objective, the keywords "sustainable development goals" and "2030 Agenda" were used, as they are the context of our research, and "quality education" as the specific concept of our study. The data were extracted in April 2020, including in the search the publications contemplated from 2015 to 2020 (including the publications of the months up to the time of the search). The search field was restricted to its presence in the title, abstract or keywords of the publication. The initial search of the descriptors registered a total of 18,894 documents, obtaining 9164 in Web of Science ("Quality education" ( $n=2246)$, "Sustainable development goals" OR "2030 Agenda" $(n=6918)$ ) and 9730 in Scopus ("Quality education" ( $n=1597)$, "Sustainable development goals" OR "2030 Agenda" $(n=8133))$. The reason for such a wide sample is that the search for these concepts, considering the stipulated search period, reports a large number of results not directly linked to the specific thematic area of our work.

\subsection{Curating Phase}

Based on the 18,894 documents, a process of refinement more akin to the object of the study was carried out. Therefore, in order to carry out a search adjusted to our subject matter, the procedure was the inclusion of one or both key words that make up the context, combined with the specific concept, the final command introduced being the following (("sustainable development goals" OR "2030 Agenda") AND "quality education"). The process of refinement meant the exclusion of a total of 18,654 documents, which shows that the specific scientific production on the object of study is not as extensive. The final sample of publications was $240(n=240), 98$ belonging to the Web of Science database and 142 to the Scopus database. This is a descriptive study based on the observation, systematization, and analysis of ten variables, taking into account other bibliometric studies in the field of education [44-51]. The time period considered for the bibliometric approach is linked to the date of enactment of the Sustainable Development Goals in 2015. The reason is that previous studies and works can address this issue and its relationship with quality in education, but not with the same sense, purpose, and universality that gave rise to the enactment of 2030 Agenda, making this specific aspect, by the United Nations, one of the key objectives to achieve the development of a sustainable world. Based on this premise, it is necessary to specify the information regarding the variables considered for the study: year, allowing us to know how the documents that make up the sample are temporarily distributed from 2015 to 2020; source types, to differentiate the publication format of the documents between articles, meetings, books, book chapters or reviews; subject area, determining in which areas of knowledge the object of study is researched; periodical publications, to find out which journals have included the subject matter in their publications; authors, to find out which main researchers are working on the subject and have the longest history in the field; institutions, to find out which institutions are pioneers in the subject matter analyzed or are devoting greater importance to its study; country, allowing us to know the countries where the institutions and authors of reference are located in SDGs, 2030 Agenda and quality education; language, determining the usual language in which the sample of publications has been prepared; publication with most impact, highlighting the publications that, at the time of the bibliometric approach, have had the greatest dissemination and impact measured by the citations received in Web of Science (WoS) and Scopus; keywords, to know which are the descriptors and main terms on which the body of publications that have been the object of analysis have been built.

In order to achieve greater precision with respect to the analysis of the subject of study, inclusion/exclusion criteria were stipulated for the different variables (Table 1). 
Table 1. Variables studies and criteria of inclusion/exclusion.

\begin{tabular}{cl}
\hline Variables & \multicolumn{1}{c}{ Criteria of Inclusion/Exclusion } \\
\hline Year & All publications from 2015 have been considered \\
Source types & All possible documents have been considered \\
Subject area & Those areas in which ten or more publications are indexed \\
Periodical Publications & Only those reviews were considered that had 2 or more articles indexed in the same database \\
Authors & They should have 2 or more publications indexed in the same database \\
Institution & There should be 4 or more publications indexed between both databases \\
Country & There should be 8 or more publications between both databases \\
Language & All languages of the texts should be contemplated \\
Keywords & There should be twenty quotations or more \\
Publications with most impact & There should be some whose frequency is at least 6 or more. \\
\hline & Source: authors' own research.
\end{tabular}

\section{Results}

Considering the 240 publications that make up the sample, in the Web of Science database $(n=98)$ $39.80 \%$ are on open access $(n=39)$, while in Scopus $(n=142)$ it is $38.02 \%(n=54)$, so that both databases have similar percentages regarding open access publications, with the number of publications in Scopus being higher. Based on this general data, we will now analyze the variables considered for the study.

\subsection{Year}

We began by analyzing the year of publication. It should be noted that an exclusion criterion was stipulated for those publications prior to 2014. The reason for this is that the United Nations General Assembly, after approving on 25 September 2015 the Agenda for development after 2015, it published on 21 October 2015 the document entitled "Transforming our world: the 2030 Agenda for sustainable development", from which research began on the themes and descriptors included in the 2030 Agenda and the corresponding objectives for sustainable development, establishing this date as the origin of the scientific literature on this reality.

Based on the results obtained in the databases (Table 2), we found that the first research articles start to be published in 2016 (10 in WoS and six in Scopus), with only one study in 2015 (Scopus) due to the date of publication of the United Nations General Assembly. In both databases, 2019 is the year with the highest number of publications (32 in WoS and 52 in Scopus). With the exception of 2016, in the remaining years the scientific production in Scopus always exceeded that of Web of Science.

Table 2. Publications per annum in the databases.

\begin{tabular}{ccc}
\hline \multirow{2}{*}{ Year } & \multicolumn{2}{c}{ Publications Number } \\
\cline { 2 - 3 } & WoS & Scopus \\
\hline 2015 & 0 & 1 \\
2016 & 10 & 6 \\
2017 & 17 & 25 \\
2018 & 23 & 31 \\
2019 & 32 & 52 \\
2020 & 16 & 27 \\
\hline
\end{tabular}

Source: authors' own research. WoS $=$ Web of Science.

As regards the evolution of research, growth has been constant and progressive (Figure 1), from the first publications in $2015(n=1)$ and $2016(n=16)$, to the greatest development in 2018 and 2019, with the latter recording the most publications $(n=84)$. However, we found a slight decline in 2020 $(n=43)$ because only documents published in the first quarter of the year were considered (up to and including April when the search was conducted). 


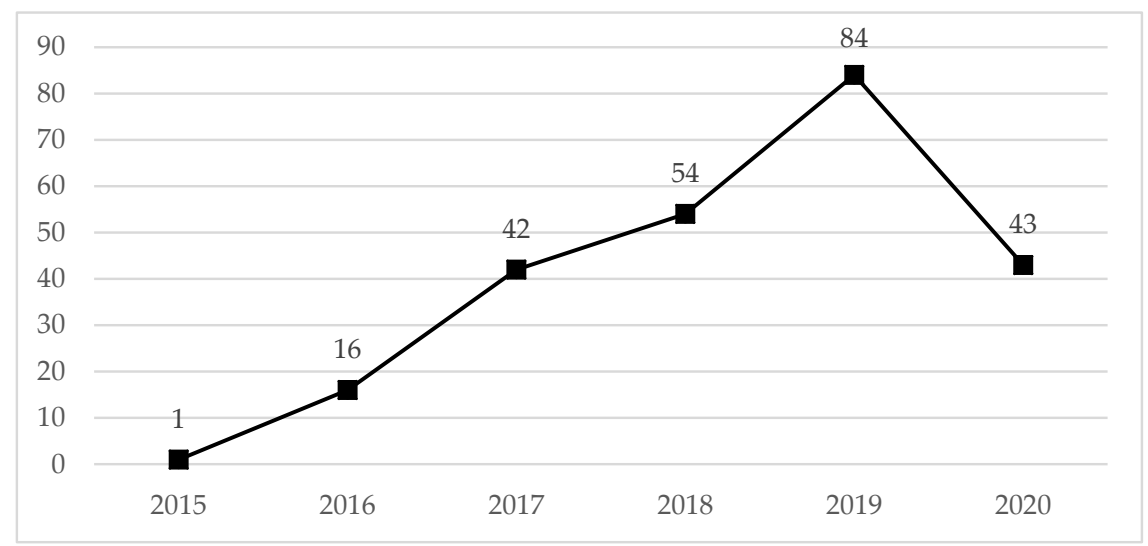

Figure 1. Evolution of scientific production.

\subsection{Source Types}

With regards to the variable publication format or type of document, publications were distributed among five typologies (Table 3): articles, communications, books, book chapters, and reviews.

Table 3. Types of document on the databases.

\begin{tabular}{ccc}
\hline \multirow{2}{*}{ Source Types } & \multicolumn{2}{c}{ Publications Number } \\
\cline { 2 - 3 } & WoS & Scopus \\
\hline Article & 75 & 96 \\
Meeting & 12 & 21 \\
Book & 8 & 0 \\
Book chapter & 0 & 18 \\
Review & 3 & 7 \\
\hline
\end{tabular}

Source: authors own research.

The majority of the registered publications are articles $(n=171)$, followed by communications ( $n=33$ ), encompassing between both formats, $85 \%$ of the analyzed research. The book chapters $(n=18)$ follow, with only a minor presence in the Scopus database and representing $7.5 \%$ of the total publications. At the opposite end, with percentages below $5 \%$, are the reviews $(4.16 \%)$ and the books $(3.33 \%)$, the latter appearing only on the Web of Science. In the cases where there are records of the typologies in both databases, the number of publications in Scopus is always greater (in articles $12.28 \%$ higher; in communications $27.76 \%$; and in reviews $40 \%$ ).

\subsection{Subject Area}

This variable is analyzed in two different tables per database, due to the fact that Web of Science (Table 4) and Scopus (Table 5) do not share unified criteria for the delimitation of the indexing areas, each establishing its own categories. It is also necessary to indicate that many of the publications attend to a multi-classification criterion, many of them belonging to more than one thematic area. Those areas that register at least 10 publications are established as inclusion criteria.

In the Web of Science we found a total of eight thematic areas that registered at least 10 publications, educational research being most frequent $(n=44)$, followed by environmental and ecological sciences $(n=35)$ and technological science $(n=34)$, including $60.75 \%$ of the indexations. The last area included is engineering as it reaches the number of publications stipulated as a filter $(n=10)$.

As for Scopus, seven areas reached the minimum required, with social sciences standing out above the rest $(n=104)$ with $45.41 \%$ of the indexations. It is followed by environmental sciences $(n=39)$ and energy $(n=31)$, with $75.98 \%$ of the records between the three. On the opposite side is psychology with a total of 11 indexations. 
Table 4. Subject area in Web of Science.

\begin{tabular}{cc}
\hline \multirow{2}{*}{ Subject Area } & Publications Number \\
\cline { 2 - 2 } & WoS \\
\hline Education educational research & 44 \\
Environmental science ecology & 35 \\
Science technology & 34 \\
Geography & 22 \\
Business economics & 17 \\
Computer science & 12 \\
Public administration & 12 \\
Engineering & 10 \\
\hline
\end{tabular}

Source: authors' own research.

Table 5. Subject area in Scopus.

\begin{tabular}{cc}
\hline Subject Area & Publications Number \\
\cline { 2 - 2 } & Scopus \\
\hline Social sciences & 104 \\
Environmental science & 39 \\
Energy & 31 \\
Business, management and accounting & 16 \\
Engineering & 15 \\
Computer science & 13 \\
Psychology & 11 \\
\hline
\end{tabular}

Source: authors' own research.

\subsection{Periodic Publications}

The fourth variable focuses on those journals that have published on the subject of study (Table 6). The criteria for inclusion are those journals that register at least two articles in some of the databases analyzed. In this sense, there are journals that are indexed only in one of the databases and others that appear in both, obtaining in the latter case the same number of registered articles.

Table 6. Reviews with greatest scientific production in the databases.

\begin{tabular}{ccc}
\hline Journals & \multicolumn{2}{c}{ Publications Number } \\
\cline { 2 - 3 } Sustainability & WoS & Scopus \\
\hline International Review of Education & 19 & 19 \\
Journal of Cleaner Production & 5 & 5 \\
Frontiers in Psychology & 5 & 5 \\
International Journal of Sustainability in Higher Education & 2 & 2 \\
Journal of Sustainable Tourism & 2 & 2 \\
World Development & 2 & 2 \\
Journal of Physics Conference Series & 3 & 3 \\
Childhood Education & 0 & 2 \\
International Review of research in Open and Distance Learning & 0 & 2 \\
\hline
\end{tabular}

Source: authors' own research.

\subsection{Authors}

In this variable we will consider those authors with the greatest scientific production on the subject (Table 7). An exclusion criterion was established for those authors who did not have two or more publications indexed in one of the databases analyzed, since if they had included those who had added a minimum of two references between them, the information would have been very broad, with a lower degree of adjustment to the authors who published most on the subject. 
Table 7. Authors with greatest scientific production in the databases.

\begin{tabular}{ccc}
\hline \multirow{2}{*}{ Author } & \multicolumn{2}{c}{ Publications Number } \\
\cline { 2 - 3 } & WoS & Scopus \\
\hline Abioye, T. & 2 & 1 \\
Ajiboye, E. & 2 & 1 \\
Omidiora, S. & 2 & 1 \\
Oyero, O. & 2 & 1 \\
Oyesomi, K. & 2 & 1 \\
del Cerro Velázquez, F. & 2 & 2 \\
\hline
\end{tabular}

Source: authors' own research.

Cerro Velázquez is the only author with two publications indexed in the Scopus database, obtaining a total of four between both databases. The rest of the researchers, as they share authorship in the publications they have made, have equally distributed their scientific production, with two publications indexed in the Web of Science and one publication in Scopus. The rest of the authors analyzed have not managed to index at least two of their publications in the same database.

\subsection{Institution}

Another interesting aspect is to know the institutions of affiliation (Table 8) of the signing authors in order to know where this line of research is acquiring most importance. It has been established as an inclusion criterion to have four or more publications indexed between both databases (Web of Science and Scopus).

Table 8. Institutions with most publications in the databases.

\begin{tabular}{ccc}
\hline \multirow{2}{*}{ Institutions } & \multicolumn{2}{c}{ Publications Number } \\
\cline { 2 - 3 } & WoS & Scopus \\
\hline University of South Africa & 5 & 5 \\
University of Toronto & 2 & 4 \\
Covenant University & 3 & 3 \\
UNESCO & 3 & 2 \\
Universidad Autónoma de Madrid & 1 & 3 \\
Universidad de Murcia & 2 & 2 \\
University of Waterloo & 2 & 2 \\
University of Liverpool & 2 & 2 \\
Universitat Rovirai Virgili & 2 & 2 \\
\hline
\end{tabular}

Source: authors' own research. UNESCO = United Nations Education, Scientific and Cultural Organisation.

The results show that the organization that has registered the most publications in the databases contemplated has been the University of South Africa (ten publications), followed by the University of Toronto and Covenant University (both with six). The presence of three Spanish universities in the list should be highlighted (Universidad Autónoma de Madrid, Universidad de Murcia, and Universitat Rovira i Virgili), all of them registering the minimum stipulated (four publications) and UNESCO itself (five publications), thus also promoting its research and publication work on thematic areas linked to its action.

\subsection{Country}

In order to analyze the variable of countries with the highest scientific production (Table 9), it has been established as a criterion for inclusion to have at least eight references or more between both databases. With this criterion, a total of 11 countries were extracted, which brings together 201 references out of the 240 analyzed, including $83.75 \%$ of the publications as a whole. 
Table 9. Countries with greatest scientific production in the databases.

\begin{tabular}{ccc}
\hline \multirow{2}{*}{ Country } & \multicolumn{2}{c}{ Publications Number } \\
\cline { 2 - 3 } & WoS & Scopus \\
\hline United Kingdom & 21 & 20 \\
Spain & 15 & 19 \\
United States & 13 & 20 \\
South Africa & 11 & 9 \\
Australia & 5 & 6 \\
Canada & 5 & 11 \\
Nigeria & 5 & 5 \\
France & 4 & 4 \\
Indonesia & 4 & 4 \\
India & 2 & 8 \\
Malaysia & 3 & 7 \\
\hline Source: authors' own research.
\end{tabular}

If we look at the countries that are having the greatest impact on the study of sustainable development objectives and 2030 Agenda linked to educational quality, we can get a sense of the international impact of the research, establishing geographically the origin of the institutions that have been most interested in the subject. The number of references in the United Kingdom stands out $(n=41)$, being the country that has researched the most on the subject $(17.08 \%$ of the total). They are followed by Spain with 34 (14.17\%), the United States with 33 (13.75\%), and South Africa with 20 $(8.33 \%)$. At the other end, meeting the established criteria, are France and Nigeria, both with eight references, which are divided equally between Web of Science and Scopus (four in each).

\subsection{Language}

In the language variable (Table 10), the different languages used in the publications that have been analyzed have been considered.

Table 10. Most used languages in publications in the databases.

\begin{tabular}{ccc}
\hline \multirow{2}{*}{ Language } & \multicolumn{2}{c}{ Publications Number } \\
\cline { 2 - 3 } & WoS & Scopus \\
\hline English & 92 & 136 \\
Spanish & 5 & 4 \\
Turkish & 1 & 1 \\
Croatian & 0 & 1 \\
\hline \multicolumn{2}{c}{ Source: authors' own research. }
\end{tabular}

As we can see, the results reflect the supremacy of English as the predominant language in the sample of publications ( $n=228$ ), bringing together $95 \%$ of them. With nine publications, Spanish is in second place (3.75\% of the total). Almost anecdotally, in the last positions, we find Turkish $(n=2)$ and Croatian $(n=1)$, with $0.83 \%$ and $0.42 \%$, respectively.

\subsection{Publications with the Most Impact}

One of the most relevant variables is the analysis of the publications with the greatest scientific impact (Table 11). In this sense, it was stipulated as a criterion to reach 20 citations or more between both databases (WoS and Scopus). A total of six articles met this criterion, to which we also calculated the number of citations per year received, so that we consider both the global impact (total accumulated citations) and year (average citations per year). 
Table 11. Most cited publication in the databases.

\begin{tabular}{|c|c|c|c|c|c|c|}
\hline Author(s) & Year & Title & Situation & WoS & Scopus & $\begin{array}{l}\text { Average Number of } \\
\text { Citations per Year }\end{array}$ \\
\hline $\begin{array}{l}\text { Chin and } \\
\text { Jacobsson }\end{array}$ & 2016 & $\begin{array}{l}\text { TheGoals.org: mobile global } \\
\text { education on the Sustainable } \\
\text { Development Goals }\end{array}$ & $\begin{array}{l}\text { Journal of Cleaner } \\
\text { Production, 123, } \\
227-229 .\end{array}$ & 21 & 30 & 10.2 \\
\hline $\begin{array}{l}\text { Bürgener } \\
\text { and Barth }\end{array}$ & 2018 & $\begin{array}{l}\text { Sustainability competencies in } \\
\text { teacher education: Making } \\
\text { teacher education count in } \\
\text { everyday school practice }\end{array}$ & $\begin{array}{l}\text { Journal of Cleaner } \\
\text { Production, } 174 \\
\text { 821-826. }\end{array}$ & 15 & 19 & 11.34 \\
\hline Owens & 2017 & $\begin{array}{l}\text { Higher education in the } \\
\text { sustainable development goals } \\
\text { framework }\end{array}$ & $\begin{array}{l}\text { European Journal of } \\
\text { Education, 52(4), } \\
414-420 .\end{array}$ & 15 & 16 & 7.75 \\
\hline $\begin{array}{l}\text { Smith and } \\
\text { Taylor }\end{array}$ & 2016 & $\begin{array}{l}\text { What Is Next for NTDs in the } \\
\text { Era of the Sustainable } \\
\text { Development Goals? }\end{array}$ & $\begin{array}{l}\text { PLOS Neglected } \\
\text { Tropical Diseases, } \\
\text { 10(7). e0004719 }\end{array}$ & 11 & 13 & 4.8 \\
\hline Sharma et al. & 2017 & $\begin{array}{c}\text { Prioritizing research for } \\
\text { integrated implementation of } \\
\text { early childhood development } \\
\text { and maternal, newborn, child } \\
\text { and adolescent health and } \\
\text { nutrition platforms }\end{array}$ & $\begin{array}{l}\text { Journal of Global } \\
\text { Health, 7(1). } 011002\end{array}$ & 8 & 13 & 5.25 \\
\hline Binns et al. & 2017 & $\begin{array}{l}\text { The Role of Public Health } \\
\text { Nutrition in Achieving the } \\
\text { Sustainable Development } \\
\text { Goals in the Asia Pacific Region }\end{array}$ & $\begin{array}{l}\text { Asia-pacific Journal } \\
\text { of Public Health. } \\
\text { 29(7), 617-624. }\end{array}$ & 9 & 11 & 5 \\
\hline
\end{tabular}

Source: authors' own research.

A significant fact is that the six articles always receive more citations on Scopus than on Web of Science. Furthermore, it is worth noting that once ordered by the total number of citations, they are also classified from highest to lowest in the citations received in both databases. Entering the analysis of scientific production, with a total of 51 citations, the publication with the most impact is entitled "TheGoals.org: mobile global education on the Sustainable Development Goals", which proposes a mobile platform through which to receive quality education and training related to the SDGs and encourage local youth actions as solutions to global challenges [52]. It is followed, with 34 citations, by the work of Bürgener and Barth [53], in which they underline the importance of initial teacher training to achieve future competent teachers committed to sustainable development, incorporating into their training the strategy of living laboratories where they become aware of aspects of the environment and its care. It is interesting to note that the average number of citations per year is higher in the second article with more scientific impact than in the first (11.34 citations per year on average versus 10.2). The study entitled "Higher education in the sustainable development goals framework" is ranked third, focusing on the analysis of the incorporation of higher education into the SDGs compared to its non-inclusion in the Millennium Development Goals [54]. This is followed by the publication that addresses the importance of education in the consideration of neglected tropical diseases in the SDGs [26], with 24 citations in total and the lowest average per year (4.8). The penultimate place, with 21 citations, is for the paper called "Prioritizing research for integrated implementation of early childhood development and maternal, newborn, child and adolescent health and nutrition platforms", which focuses on analyzing improvements for platforms on health, nutrition, and child development within the time frame set for the SDGs [55]. The last article, which exceeds the exclusion criterion (20 citations), focuses on improving aspects related to child mortality, with a direct impact on the achievement of the fourth objective of the SDGs on quality education [56].

\subsection{Keywords}

The last variable is key words (Table 12), thus considering the descriptors that define the publications linked to the subject matter of the study. However, it should be clarified that the analysis 
could only be carried out in the Scopus database, since the Web of Science does not include information regarding the terms used in the keywords. Frequency has been set as an exclusion criterion, including only those that have appeared on six or more occasions.

Table 12. Most frequent keywords in the databases.

\begin{tabular}{cc}
\hline Keyword & Frequency \\
\hline Sustainable development & 57 \\
Sustainable Development Goals & 31 \\
Education & 29 \\
Quality Education & 25 \\
Planning & 18 \\
Sustainability & 17 \\
Learning & 15 \\
Sustainable Development Goals (SDGs) & 15 \\
United Nations & 14 \\
Higher Education & 11 \\
Human & 8 \\
SDGs & 8 \\
Student & 8 \\
Students & 8 \\
Teaching & 8 \\
Lifelong Learning & 7 \\
Environmental Protection & 7 \\
Female & 6 \\
Literacy & 6 \\
Primary Education & 6 \\
Public Health & 6 \\
\hline
\end{tabular}

Source: authors' own research.

The most frequently used keywords were "Sustainable development" (57 times), "Sustainable Development Goals" (31 times), "Education" (29 times), and "Quality education" (25 times), thus coinciding with the thematic area of our study. The rest of the words obtained frequencies lower than 20, being always equal or higher than six which was the inclusion criterion to be met. All the keywords that fulfilled the stipulated criteria are related to educational, environmental, and health issues, coinciding with the main focus of the study. The VOSviewer software was used to extract the relational nodes, reflecting the relationship generated between the keywords (Figure 2). In this sense, the size of the words and of the node indicates the frequency of appearance and the number of connections with other descriptors. The different colors reflect the grouping of these words into different sets.

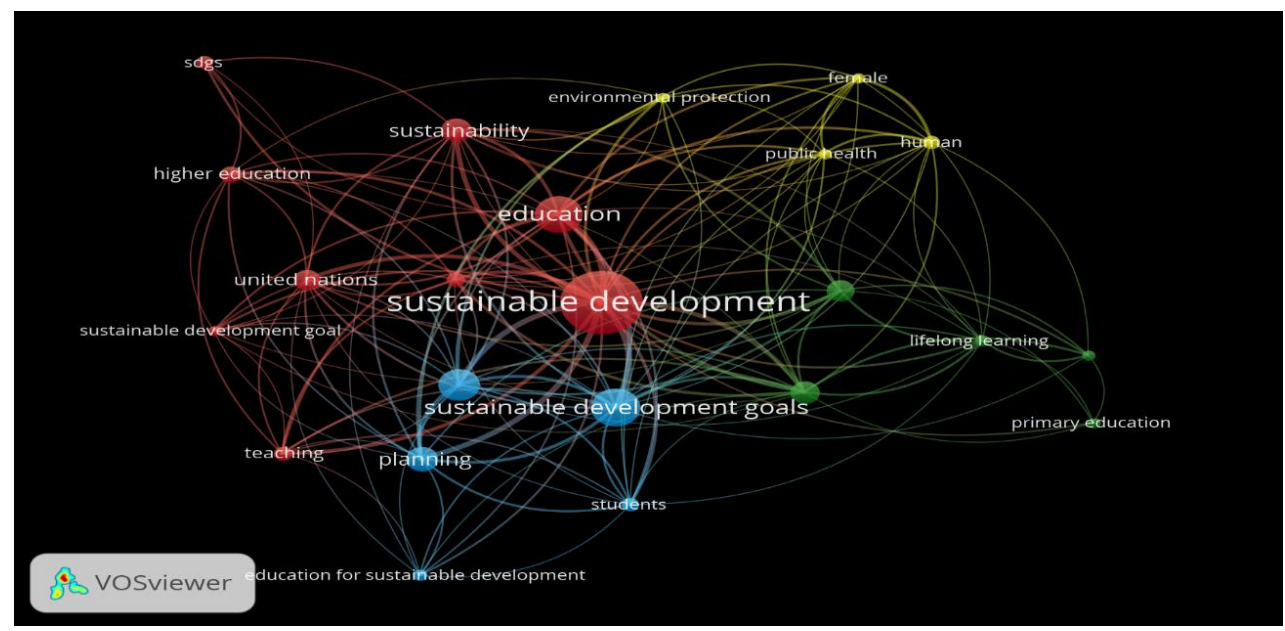

Figure 2. Evolution of scientific production. 


\section{Discussion}

The bibliometric approach arises from academic interest in obtaining a general vision of the scientific production developed around this subject, enabling us to know the characteristics of the publications made and opening a horizon of new proposals and lines of research. In this sense, the study of educational quality as one of the Sustainable Development Goals stipulated in 2030 Agenda, is a new scientific field now in full growth. Let us not forget that education in the SDGs is not only an objective in itself, but that its development is necessary for the achievement of the rest of the objectives [23,28].

As we have seen in the results, the greatest scientific production is concentrated between 2018 and 2019 (57.5\% of the total number of references analyzed), reflecting a notable evolution in the number of publications since its appearance in 2015, coinciding with the publication of the United Nations General Assembly [9]. This fact, together with the fact that the assessment of the fulfillment of the Sustainable Development Goals is stipulated for the year 2030, favors a context in which research and studies on this subject will continue to multiply in the coming years due to the scientific interest it arouses. In the same vein, the work of Cebrián, Junyent, and Mulà [28], highlights the need for more research efforts for the acquisition, implementation, and improvement of skills related to sustainability in education. If we want to foster reflective processes and the development of students' critical thinking about the Sustainable Development Goals (key elements for environmental well-being and our survival as a species), we need to implement proposals, interventions, and projects through which they can work towards quality education.

On the other hand, coinciding with other bibliometric studies [51], the largest record of publications was in the form of scientific articles (71.25\%) followed by conference papers $(13.75 \%)$, being together $85 \%$ of the publications analyzed in this work.

With regard to the thematic area, considering the requirement to register at least 10 publications in this study variable, the publications that are indexed on the Web of Science do so primarily in the field of educational research $(23.66 \%)$, while on Scopus they are linked to the area of social sciences $(45.41 \%)$. In both databases, the second thematic area is environmental sciences, with similar results (18.82\% in WoS and 17.03\%). In this sense, the priority presence of these areas is related to the theme of sustainable development and the role that educational quality (an area of educational sciences, in turn a sub-area of social sciences and humanities) plays in the objectives stipulated in 2030 Agenda [24,30].

If we look at the indexed journals that have the most references on the subject of study, we find three results, both in Web of Science and Scopus: Sustainability, focused on the environmental, cultural, economic, and social sustainability of human beings, with 19 references; International Review of Education, whose priority editorial line is policies for lifelong learning in international and comparative contexts, with five articles; and Journal of Cleaner Production, whose focus is clean production, the environment, and sustainability, also with five references. These three publications account for only $24.16 \%$ of the publications, which denotes a great variety with respect to other journals, publishers, and scientific events that have addressed this issue. In this same sense, it is also relevant to highlight that among the publications with the most scientific impact that meet the inclusion criteria (20 or more citations received), we only found two articles from the Journal of Cleaner Production; none of the other journals published more articles on the subject of study. Regarding the authors with the highest scientific production, only six authors managed to index two of their publications in the same database (either Web of Science or Scopus); none achieved a frequency of more than two articles. This fact, according to the total number of publications analyzed, reflects the variety of researchers that are tackling this subject without having a wide trajectory in terms of the number of publications carried out. The University of South Africa, the University of Toronto, and Covenant University stand out as institutions of reference on the subject of study, followed by UNESCO. It should be noted that the sum of all the publications indexed by institutions that have met the criterion (registering at least four publications in the two databases) represents only $19.58 \%$ of the total number of documents published. This low number of publications associated with each institution, based on the affiliation of the authors, together with the previously commented variable of authorship, reflects the initial situation in which 
this line of research was found, and therefore neither authors nor groups with a broad tradition in the subject still exist.

Taking into account the internationalization of publications, it is interesting to highlight the representation of the five continents among the countries with the highest level of scientific production. The four countries with the highest number of publications, including the United Kingdom, Spain, the United States, and South Africa, account for $53.33 \%$ of the total number of references. As for language, English is the language par excellence of the scientific publications considered in the bibliometric approach in both databases, with $95 \%$ of the total, leaving the rest of publications in other languages as something practically anecdotal.

With regard to the publications with the greatest impact, we found different themes linked to the achievement of quality education within the SDGs: focused on training, both in the improvement of the use of educational platforms and in the importance of initial teacher training [52,53]; in higher education, analyzing the importance of its role [54]; and in early childhood, both to reduce infant mortality and to improve platforms dedicated to attending consultations on early childhood development $[55,56]$.

These publications emphasize key aspects of achieving quality education, such as improving teacher education and training and raising awareness on the importance of sustainable development and improving school conditions in many areas of the world and reducing the gap with poor countries. To achieve this, investment in scholarships, staff training, school construction, and improved access to water and electricity in schools, among other measures, is needed.

To achieve all this, actions are needed from the different political, economic, and educational spheres in order to improve the social and environmental reality. Previous research on educational quality and sustainable development is along the same lines, focusing on the development of competencies, skills, and abilities in students that will allow them to improve their reality and safeguard that of tomorrow's societies $[14,15,28]$, which is the focus that should be promoted and further strengthened at the scientific level.

In terms of keywords, those linked to the subject of study predominate, including among them most widely used "Sustainable development", "Sustainable development goals", "Education", and "Quality education". In this way, the publications analyzed delve deeper into how educational quality, as one of the SDGs, favors a positive and enriching relationship between the field of education and sustainable development $[15,25,32]$.

\section{Conclusions}

We would like to highlight the interest of this study in offering detailed knowledge about the impact of publications on educational quality in the context of 2030 Agenda and the Sustainable Development Goals, thus becoming a starting point for all those researchers who wish to investigate this thematic area from a multi-faceted vision of reality.

We must consider, based on the results found in the bibliometric approach, that it is a subject in the process of development, with a progressive and continuous growth, where there are still no institutions or authors that are references due to the low production, thus confirming our starting hypothesis. This situation, in the face of a key issue such as sustainability, highlights the need to implement policies at a global level that focus on various related actions, with both theoretical and practical implications. Firstly, it is necessary to finance research, development, and innovation $(R+D+i)$ work in this area, as the proposals to be undertaken must be based on and supported by scientific evidence that provides guidelines and factors to be considered and applied in decision-making. In this way, we will generate a corpus of scientific knowledge around this reality, which will allow us to adopt measures and actions consistent with the needs detected. After that, and secondly, skills at an educational level for the development of sustainability must be incorporated. Training processes must be the axis on which to build the changes, transformations, and improvements that we need as a society, so educational policies, the development of the curriculum, and the definition of competencies must incorporate the theme of sustainability and its practical application. As we reflect in the theoretical foundation, the educational 
context becomes the ideal framework to promote the understanding and internalization of actions and behaviors in pursuit of sustainability, with the foundations of 2030 Agenda having to be latent in the processes of debate and reflection on political, economic, social, cultural, and educational improvement at the global level. This is a reality that must be directed towards students, from the earliest ages and throughout their schooling [12], and also to teachers, in initial and continuing training, since they will become examples, guides, and promoters of values and attitudes [57-59], with their commitment to sustainability being key. In this sense, we cannot forget the fulfillment of the indicators linked to the objective of quality in education, which is another responsibility and task to be addressed by teachers and educational institutions. Another relevant aspect is, thirdly, to improve the infrastructures and the inclusive attention to the students. Quality in education needs to have the necessary means and all those that can positively influence the teaching-learning process to be effective and efficient [24], being complex to focus on the comprehensive and holistic development of students when there is no drinking water, electricity or basic resources for the development of the so-called competences of the twenty-first century [60]. In addition, we need schools that include the entire student body and avoid segregation and differences due to class, resources, gender, race, religion or any other factor. A quality education aspires to each student achieving his or her best, and this is a reality that cannot remain in theory but must be put into practice. Therefore, it is necessary to consider all the factors or elements that make this situation difficult or harmful in order to eradicate them. Finally, we need to promote cooperation as a means of fighting inequalities and injustices. There are different actions $(0.7 \%$ of the Gross National Product) that show these desires to collaborate, and they should form a capital part of the social policies of the main world powers and all those countries that are not in situations of extreme poverty. Sustainable development is faced from the whole of humanity, leaving aside borders, differences, and interests if we want to safeguard the common good.

With regard to the limitations, the final sample of publications analyzed has been small, due to the fact that the elements contemplated had a separate route and dissemination but were not combined in the same research context on too many occasions. As a result, the decision was taken to not to implement more specific bibliometric techniques and instead carry out a more descriptive study of the current scientific situation in this field.

Among the future lines of research, a bibliometric study will be carried out in the medium term (linked to the increase in scientific production in this field of knowledge) using library techniques such as bibliographic coupling, citation analysis, co-citation analysis, co-word analysis, co-authorship analysis or prestige analysis. In this way, it will be possible to examine the past and future growth of the publications and to know the intellectual structure of this subject in a deeper and more objective way. In addition, it is proposed to incorporate a content analysis to deepen the dimensions that arise from the quantitative analysis. This will allow us to know, from a qualitative and interpretative approach, the most relevant issues linked to the concept of quality in education in the context of the SDGs and 2030 Agenda, analyzing more thoroughly the content of these publications and the relationships that may arise from the connection between them.

Author Contributions: Conceptualization, E.G.G. and A.C.A.; methodology, E.C.M.; software, E.C.M.; investigation, E.G.G. and A.C.A.; writing-original draft preparation, E.G.G.; writing-review and editing, A.C.A.; supervision, E.C.M. All authors have read and agreed to the published version of the manuscript.

Funding: This research received no external funding.

Conflicts of Interest: The authors declare no conflicts of interest.

\section{References}

1. United Nations (UN). Informe Brundtland, "Nuestro Futuro en Común”. 1987. Available online: www.un. org/es/comun/docs/?sym-bol=A/42/427 (accessed on 20 May 2020).

2. World Education Forum (WEF). The Dakar Framework for Action. Education for all: Meeting our Collective Commitments. Paris: UNESCO. 2000. Available online: https://unesdoc.unesco.org/ark:/48223/pf0000121147 (accessed on 19 May 2020). 
3. Hulme, D. The Millennium Development Goals (MDGs). A Short History of the World's Biggest Promise; The University of Manchester Brooks World Poverty Institute: Manchester, UK, 2009.

4. United Nations (UN). Una Vida Digna Para Todos: Acelerar el Logro de los Objetivos de Desarrollo del Milenio y Promover la Agenda de las Naciones Unidas para el Desarrollo Después de 2015, Informe del Secretario General de NNUU. 2013. Available online: http://www.un.org/es/comun/docs/?symbol=A/68/202 (accessed on 17 May 2020).

5. United Nations (UN). United Nations Millennium Declaration. A/RES/55/2. New York: United Nations. 2000. Available online: http://www.un-documents.net/a55r2.htm (accessed on 18 May 2020).

6. Gabay, C. Special forum on the millennium development goals: Introduction. Globalizations 2015, 12, 576-580. [CrossRef]

7. United Nations (UN). Transforming Our World. The 2030 Agenda for Sustainable Development. New York: United Nacion. 2015. Available online: https://sustainabledevelopment.un.org/content/documents/ 21252030\%20Agenda\%20for\%20Sustainable\%20Development\%20web.pdf (accessed on 20 May 2020).

8. Obersteiner, M.; Walsh, B.; Frank, S.; Havlík, P.; Cantele, M.; Liu, J.; Palazzo, A.; Herrero, M.; Lu, Y.; Mosnier, A.; et al. Assessing the land resource-food price nexus of the Sustainable Development Goals. Sci. Adv. 2016, 2, 1501499. [CrossRef] [PubMed]

9. United Nations (UN). Global Indicator Framework for the Sustainable Development Goals and Targets of the 2030 Agenda for Sustainable Development; A/RES/71/313; United Nations: New York, NY, USA, 2018.

10. Eurostat. EU SDG Indicator Set 2018: Result of the Review in Preparation of the 2018 Edition of the EU SDG Monitoring Report. Available online: https://ec.europa.eu/eurostat/documents/276524/7736915/EU+SDG+ indicator+set+2018+-+public+web+version+with+cover+note/c86cd681-a537-4f0c-9680-197f04888f12 (accessed on 20 May 2020).

11. Körfgen, A.; Förster, K.; Glatz, I.; Maier, S.; Becsi, B.; Meyer, A.; Kromp-Kolb, H.; Stötter, J. It's a Hit! Mapping Austrian Research Contributions to the Sustainable Development Goals. Sustainability 2018, 10, 3295. [CrossRef]

12. Giangrande, N.; White, R.M.; East, M.; Jackson, R.; Clarke, T.; Saloff Coste, M.; Penha-Lopes, G. A Competency Framework to Assess and Activate Education for Sustainable Development: Addressing the UN Sustainable Development Goals 4.7 Challenge. Sustainability 2019, 11, 2832. [CrossRef]

13. Sanahuja, J.A.; Tezanos, S. Del milenio a la sostenibilidad: Retos y perspectivas de la Agenda 2030 para el desarrollo sostenible. Política Soc. 2017, 54, 533-555. [CrossRef]

14. Castillo, C.; Da Silva, J.; Monsueto, S. Objectives of sustainable development and youth employment in Colombia. Sustainability 2020, 12, 991. [CrossRef]

15. Lai, Y.-C.; Peng, L.-H. Effective Teaching and Activities of Excellent Teachers for the Sustainable Development of Higher Design Education. Sustainability 2020, 12, 28. [CrossRef]

16. Ali, S.; Hussain, T.; Zhang, G.; Nurunnabi, M.; Li, B. The Implementation of Sustainable Development Goals in "BRICS" Countries. Sustainability 2018, 10, 2513. [CrossRef]

17. Rodríguez, L. El desarrollo de las ONG de México y su coincidencia con los Objetivos para el Desarrollo Sostenible de Naciones Unidas. CIRIEC-España Rev. Econ. Pública Soc. Coop. 2017, 91, 59-84. [CrossRef]

18. Boeren, E. Understanding Sustainable Development Goal (SDG) 4 on "quality education" from micro, meso and macro perspectives. Int. Rev. Educ. 2019, 65, 277-294. [CrossRef]

19. Bergman, Z.; Bergman, M.M.; Fernandes, K.; Grossrieder, D.; Schneider, L. The Contribution of UNESCO Chairs toward Achieving the UN Sustainable Development Goals. Sustainability 2018, 10, 4471. [CrossRef]

20. World Education Forum (WEF). Incheon Declaration and Framework for Action for the Implementation of Sustainable Development Goal 4. Towards Inclusive and Equitable Quality Education and Lifelong Learning Opportunities for All. Education 2030. Paris: UNESCO. 2016. Available online: http://unesdoc.unesco.org/ images/0024/002456/245656e.pdf (accessed on 20 May 2020).

21. United Nations Educational, Scientific and Cultural Organisation (UNESCO). Unpacking Sustainable Development Goal 4 Education 2030. 2017. Available online: http://unesdoc.unesco.org/images/0024/002463/ 246300E.pdf (accessed on 18 May 2020).

22. Ministerio de Derechos Sociales y Agenda 2030. Objetivos de Desarrollo Sostenible. 2020. Available online: https://www.agenda2030.gob.es/objetivos (accessed on 20 May 2020).

23. Osei Kwadwo, V.; Akua Konadu, O. Can Ghana Afford the Sustainable Development Goal on Education? Afr. Educ. Rev. 2020, 17, 177-197. [CrossRef] 
24. Del Cerro, F.; Morales, G. Augmented Reality and Mobile Devices: A Binominal Methodological Resource for Inclusive Education (SDG 4). An example in Secondary Education. Sustainability 2018, 10, 3446. [CrossRef]

25. Del Cerro, F.; Rivas, F. Estudio de un caso de enseñanza de materias STEM a través del ecourbanismo apoyado por herramientas avanzadas de diseño, en el horizonte 2030 de objetivos de desarrollo sostenible (ODS). Rev. Educ. Distancia 2018, 58, 1-22.

26. Smith, J.; Taylor, E.M. What Is Next for NTDs in the Era of the Sustainable Development Goals? PLoS Negl. Trop. Dis. 2016, 10, e0004719. [CrossRef] [PubMed]

27. Fonseca, L.; Carvalho, F. The Reporting of SDGs by Quality, Environmental, and Occupational Health and Safety-Certified Organizations. Sustainability 2019, 11, 5797. [CrossRef]

28. Alonso-García, S.; Aznar-Díaz, I.; Cáceres-Reche, M.P.; Trujillo-Torres, J.M.; Romero-Rodríguez, J.M. Systematic Review of Good Teaching Practices with ICT in Spanish Higher Education. Trends and Challenges for Sustainability. Sustainability 2019, 11, 7150. [CrossRef]

29. Perales, M.; Pedraza, L.; Moreno, P.; Bocos, E. Challenges of Online Higher Education in the Face of the Sustainability Objectives of the United Nations: Carbon Footprint, Accessibility and Social Inclusion. Sustainability 2019, 11, 5580. [CrossRef]

30. Venkataraman, B. Education for sustainable development. Environ. Mag. 2009, 51, 8-10. [CrossRef]

31. Moya, I.; Ribes, G.; Sanahuja, G. Towards Sustainability in University Education. Improving University Graduates Chances of Employability by Participation in a High Achievement Academic Program. Sustainability 2020, 12, 680. [CrossRef]

32. Cebrián, G.; Junyent, M.; Mulà, I. Competencies in Education for Sustainable Development: Emerging Teaching and Research Developments. Sustainability 2020, 12, 579. [CrossRef]

33. United Nations (UN). Doce Millones de Niños no Pisarán Jamás un Aula Escolar. 2019. Available online: https://news.un.org/es/story/2019/09/1462072 (accessed on 20 May 2020).

34. De la Rosa, D.; Giménez, P.; De la Calle, C. Educación para el desarrollo sostenible: El papel de la universidad en la Agenda 2030. Prisma Social. Rev. de Cienc. Soc. 2019, 25, 180-202.

35. Ardanuy, J. Breve Introducción a la Bibliometría; University of Barcelona: Barcelona, España, 2012; pp. 1-25.

36. Caviggioli, F.; Ughetto, E. A Bibliometric Analysis of the Research Dealing with the Impact of Additive Manufacturing on Industry, Business and Society. Int. J. Prod. Econ. 2019, 208, 254-268. [CrossRef]

37. Khanra, S.; Dhir, A.; Mäntymäki, M. Big data analytics and enterprises: A bibliometric synthesis of the literature. Enterp. Inf. Syst. 2020, 14, 737-768. [CrossRef]

38. Bhatt, Y.; Ghuman, K.; Dhir, A. Sustainable manufacturing. Bibliometrics and content analysis. J. Clean. Prod. 2020, 260, 120988. [CrossRef]

39. Di Stefano, G.; Peteraf, M.; Veronay, G. Dynamic capabilities deconstructed: A bibliographic investigation into the origins, development, and future directions of the research domain. Ind. Corp. Chang. 2010, 19, 1187-1204. [CrossRef]

40. Fahimnia, B.; Sarkis, J.; Davarzani, H. Green Supply Chain Management: A Review and Bibliometric Analysis. Int. J. Prod. Econ. 2015, 162, 101-114. [CrossRef]

41. Zhu, J.; Hua, W. Visualizing the knowledge domain of sustainable development research between 1987 and 2015: A bibliometric analysis. Scientometrics 2017, 110, 893-914. [CrossRef]

42. Olawumi, T.O.; Chan, D.W. A scientometric review of global research on sustainability and sustainable development. J. Clean. Prod. 2018, 183, 231-250. [CrossRef]

43. Hassan, S.U.; Haddawy, P.; Zhu, J. A bibliometric study of the world's research activity in sustainable development and its sub-areas using scientific literature. Scientometrics 2014, 99, 549-579. [CrossRef]

44. Abad-Segura, E.; González-Zamar, M.D.; Luque, A.; Morales, M.B. Sustainability of educational technologies: An approach to augmented reality research. Sustainability 2020, 12, 4091. [CrossRef]

45. Ambrosio, A.B.; da Silva-Oliveira, K.D.; Pereira, R.S. Education for advancing the implementation of the Sustainable Development Goals: A systematic approach. Int. J. Manag. Educ. 2019, 17, UNSP 100322.

46. Calabuig-Moreno, F.; González-Serrano, M.H.; Fombona, J.; García-Tascón, M. The Emergence of Technology in Physical Education: A General Bibliometric Analysis with a Focus on Virtual and Augmented Reality. Sustainability 2020, 12, 2728. [CrossRef]

47. Colomo, E.; Sánchez, E.; Fernández, J.M.; Trujillo, J.M. SPOC y formación del profesorado: Aproximación bibliométrica y pedagógica en Scopus y Web of Science. REIFOP 2020, 23, 37-51. [CrossRef] 
48. Hallinger, P.; Chatpinyakoop, C. A Bibliometric Review of Research on Higher Education for Sustainable Development, 1998-2018. Sustainability 2019, 11, 2401. [CrossRef]

49. Marín-Marín, J.A.; López-Belmonte, J.; Fernández-Campoy, J.M.; Romero-Rodríguez, J.M. Big data in education. A bibliometric review. Soc. Sci. 2019, 8, 223. [CrossRef]

50. Matas, A.; Leiva, J.J.; Franco, P.D. Big data irruption in education. Píxel-Bit 2020, 57, 59-90. [CrossRef]

51. Rodríguez-García, A.M.; Trujillo, J.M.; Sánchez, J. Impacto de la productividad científica sobre competencia digital de los futuros docentes: Aproximación bibliométrica en scopus y Web of Science. Rev. Complut. Educ. 2019, 30, 293-316. [CrossRef]

52. Chin, A.; Jacobson, T. TheGoals.org: Mobile global education on the Sustainable Development Goals. J. Clean. Prod. 2016, 123, 227-229. [CrossRef]

53. Bürgener, L.; Barth, M. Sustainability competencies in teacher education: Making teacher education count in everyday school practice. J. Clean. Prod. 2018, 174, 821-826. [CrossRef]

54. Owens, T.L. Higher education in the sustainable development goals framework. Eur. J. Educ. 2017, 52, 414-420. [CrossRef]

55. Sharma, R.; Gaffey, M.F.; Alderman, H. Prioritizing research for integrated implementation of early childhood development and maternal, newborn, child and adolescent health and nutrition platforms. J. Glob. Health 2017, 7, 011002. [CrossRef] [PubMed]

56. Binns, C.; Lee, M.K.; Low, W.Y. The Role of Public Health Nutrition in Achieving the Sustainable Development Goals in the Asia Pacific Region. Asia Pac. J. Public Health 2017, 29, 617-624. [CrossRef] [PubMed]

57. Esteban, F.; Mellen, T. ¿Por qué quieres ser maestro? ¿Cómo es un buen maestro? Ideas para la formación universitaria. Bordón 2016, 68, 185-198. [CrossRef]

58. Colomo, E.; Aguilar, Á.I. ¿Qué tipo de maestro valora la sociedad actual? Visión social de la figura docente a través de Twitter. Bordón 2019, 71, 9-24. [CrossRef]

59. Sanderse, W. The meaning of role modelling in moral and charactereducation. J. Moral Educ. 2013, 42, $28-42$. [CrossRef]

60. Almerich, G.; Suárez-Rodríguez, J.; Díaz-García, I.; Orellana, N. Estructura de las competenias del siglo XXI en alumnado del ámbito educativo. Factores personales influyentes. Educación XX1 2020, 23, 45-74. [CrossRef]

(C) 2020 by the authors. Licensee MDPI, Basel, Switzerland. This article is an open access article distributed under the terms and conditions of the Creative Commons Attribution (CC BY) license (http://creativecommons.org/licenses/by/4.0/). 